\title{
The Stockholm Declaration and the Structure and Processes of International Environmental Law
}

\author{
Jutta Brunnée
}

\author{
Version Post-print/accepted manuscript \\ Citation Brunnée, Jutta, The Stockholm Declaration and the Structure and \\ (published version) Processes of International Environmental Law (July 22, 2009). THE \\ FUTURE OF OCEAN REGIME BUILDING: ESSAYS IN \\ TRIBUTE TO DOUGLAS M. JOHNSTON, Aldo Chircop, Ted \\ McDorman, eds., pp. 41-62, Kluwer Law, 2008.
}

Publisher's Statement This is the peer reviewed version of Brunnée, Jutta, The Stockholm Declaration and the Structure and Processes of International Environmental Law (July 22, 2009). THE FUTURE OF OCEAN REGIME BUILDING: ESSAYS IN TRIBUTE TO DOUGLAS M. JOHNSTON, Aldo Chircop, Ted McDorman, eds., pp. 41-62, Kluwer Law, 2008.

This article can be found in its final form at:

10.1163/ej.9789004172678.i-786.11

\section{How to cite TSpace items}

Always cite the published version, so the author(s) will receive recognition through services that track citation counts, e.g. Scopus. If you need to cite the page number of the author manuscript from TSpace because you cannot access the published version, then cite the TSpace version in addition to the published version using the permanent URI (handle) found on the record page.

This article was made openly accessible by $\mathbf{U}$ of 'T Faculty. Please tell us how this access benefits you. Your story matters. 


\title{
The Stockholm Declaration and the Structure and Processes of International Environmental Law
}

\author{
Jutta Brunnée *
}

\section{INTRODUCTION}

In reading commentary on the Stockholm Declaration on the Human Environment ${ }^{1}$ that was offered at the time, one is struck by the overwhelming focus on the fault lines between North and South that the conference put into the spotlight. ${ }^{2}$ To fully appreciate why the declaration is justly seen today as a historical marker, ${ }^{3}$ it is essential to recall that the Stockholm Conference and its output were, indeed, shaped by the dramatically different views of developed and developing countries on matters of environment and development. By all accounts, the initial impetus for the Stockholm Conference came from growing concerns of industrialized countries over transboundary pollution and hazardous wastes. ${ }^{4}$ The conference was to raise awareness of the international nature of environmental concerns and to promote a sense of collective responsibility of states. By contrast, developing countries tended to see pollution as a by-product of Northern industrialization and, to the extent that it was of concern in the South, as a consequence of poverty and underdevelopment. Thus, to engage developing countries in the Stockholm Conference, it had to acknowledge the environment-development interface as at the core of a collective response to environmental degradation. ${ }^{5}$ The historical significance of the Stockholm Declaration lies in the fact that it was the first major international document that cast environmental concerns as global concerns and that highlighted development issues as integral to these concerns. ${ }^{6}$

\footnotetext{
* Professor of Law, University of Toronto. I thank Asher Alkoby for his excellent research assistance in the preparation of this article.
} 
The Stockholm Declaration, therefore, laid the foundation for a shift in international environmental law from its predominant focus on transboundary pollution to a conceptual framework with a much broader outlook. I deliberately say, "laid the foundation," because, in strictly legal terms, the focus of the declaration remained on transboundary pollution. As Alexandre Kiss observes in his contribution to this volume, the legal core of the Stockholm Declaration is Principle 21, the rule balancing the sovereign rights of states to use their territories and their obligations to avoid transboundary harm. While the majority of the declaration's provisions actually focus on global, intertemporal, and developmental concerns that reach far beyond the scope of Principle 21, they are cast as policy statements rather than in legal language. Strictly speaking, then, the Stockholm Declaration did not expand the conceptual framework of international environmental law. Yet, it did foreshadow, to a remarkable degree, the framework within which international environmental lawyers operate today.

My goal in this paper is to reflect on the impact of the Stockholm Declaration in light of the evolution of the structure and processes of international environmental law since 1972. ${ }^{7}$ I will first illustrate how the "structure" of international environmental law has changed from a transboundary, bilateral framework to a global framework, which seeks to take into account considerations of both intra- and intergenerational equity. Second, I will suggest that this change in structure has been accompanied by a broadening of the "processes" of international environmental law to encompass a range of lawmaking methods. We are no longer looking only to customary or treaty norms to shape international environmental relations.

\section{The Changing STRUCTURE OF INTERNATIONAL ENVIRONMENTAL LAW}

In 1972, the structure of international environmental law was defined by principles derived from the balancing and mutual

limitation of sovereign rights. Much as domestic environmental 
law tended to evolve initially from concepts such as nuisance, abuse of rights, and other principles governing neighborhood relationships, international environmental law originated in the idea that one state's right to use its territory had to find its limit in another state's right to be free from unreasonable interference. ${ }^{8}$ Principle 21 of the Stockholm Declaration reflects this mutual limitation paradigm.

Principle 21, of course, remains one of the core principles of international environmental law and it continues to furnish a useful ground-rule for international environmental relations. ${ }^{9}$ However, it is also evident that, conceptually, the principle falls well short of what is needed to address international environmental concerns. Suffice it to point to three factors. First, Principle 21 balances competing contemporary interests and thus cannot capture the potential intertemporal impacts of states' activities. Second, given its focus on transboundary pollution, Principle 21 is largely "bilateral" in outlook. To be sure, Principle 21 alludes to a broader context by calling for the prevention of harm to "areas beyond the limits of national jurisdiction." However, it remains unclear who would be entitled to demand compliance on behalf of these areas. In other words, Principle 21 hints at the existence of an obligation owed erga omnes, but remains hamstrung by the unresolved question of the extent to which states other than the "injured state" are entitled to invoke state responsibility. ${ }^{10} \mathrm{~A}$ third factor rests in the dilemmas and practical problems of applying Principle 21 in the face of serious capacity problems on the part of developing countries. These three factors suggest only some of the barriers to applying Principle 21 to global concerns such as ozone depletion, climate change, or loss of biodiversity.

Since 1972, the structure of international environmental law has been growing and shifting in significant ways. Principle 21 is now flanked by a conceptual framework that captures more fully the global, intertemporal, and equity dimensions of the international environmental challenge. In the context of this paper, it is not possible to provide a comprehensive account of the relevant conceptual developments. I will, therefore, focus on five 


\section{Jutta Brunnée}

concepts that best reflect the shifts that I have traced out: common concern of humankind, common but differentiated responsibilities, sustainable development, intergenerational equity, and the precautionary principle.

\section{Common Concern of Humankind}

Unlike Principle 21, the concept of common concern does not spell out a specific rule for the conduct of states. Nonetheless, it signals that states' freedom of action may be subject to limits even where other states' sovereign rights are not affected in the transboundary sense envisaged by Principle 21. Such limits flow from the fact that the concept identifies certain issues as of concern to all members of the international community. It entitles, and perhaps even requires, all states to participate in international efforts to address the concern. ${ }^{11}$ Examples of issues that were explicitly identified as common concerns over the last ten years or so include climate change and its adverse effects ${ }^{12}$ and the conservation of biological diversity. ${ }^{13}$ As these examples illustrate, the concept of common concern has the potential to mandate international cooperation to counter the degradation of "areas beyond the limits of national jurisdiction," of global resources such as the atmosphere, and even of resources physically located within the territory of individual states. While Principle 21 might suggest duties to protect areas beyond jurisdiction, it does not apply to global resources and does not restrict a state's use of its own resources except vis-à-vis other states that suffer specific transboundary injury. In sum, the concept of common concern responds to the "globalization" of environmental concerns and thus signals several fundamental shifts in the structure of international environmental law since the adoption of the Stockholm Declaration.

\section{Common but Differentiated Responsibilities}

The concept of common but differentiated responsibilities is closely connected to that of common concern and expresses the 
linkages between global environmental protection and the demands of equity between South and North. These linkages are encapsulated in Principle 7 of the Rio Declaration. The principle refers to the idea of common concern in a somewhat roundabout manner, calling on states to “. . . cooperate in a spirit of global partnership to conserve, protect and restore the health and integrity of the Earth's ecosystems.” It then continues as follows:

In view of the different contributions to global environmental degradation, States have common but differentiated responsibilities. The developed countries acknowledge the responsibility that they bear in the international pursuit of sustainable development in view of the pressures their societies place on the global environment and of the technologies and financial resources they command. ${ }^{14}$

The relationship of common concerns and differentiated responsibilities is also expressed in the preamble to the Climate Change Convention, which acknowledges

. . . that the global nature of climate change calls for the widest possible cooperation by all countries and their participation in an effective and appropriate international response, in accordance with their common but differentiated responsibilities and respective capabilities and their social and economic conditions. ${ }^{15}$

Whereas the Climate Convention explicitly mentions common but differentiated responsibilities, ${ }^{16}$ other global agreements, such as the Montreal Protocol on Substances That Deplete the Ozone Layer $^{17}$ and the Biodiversity Convention, ${ }^{18}$ reflect the underlying idea through differentiation in the obligations of developed and developing countries. ${ }^{19}$ Taken together, existing instruments and practice suggest that states are paying attention to considerations of equity in international environmental relations and recognize 


\section{Jutta Brunnée}

that approaches to global concerns must reflect both the states' contributions to a given problem, and their abilities to address it. The practical manifestations of the concept range from differentiation of commitments in terms of timelines or degree ${ }^{20}$ to provision of technical and financial assistance to developing countries, $^{21}$ and even to contingency of developing country compliance upon provision of such assistance. ${ }^{22}$ Common but differentiated responsibilities thus represent another fundamental set of shifts in the conceptual structure of international environmental law. At least some of its norms, it would seem, no longer necessarily have equal application to all states. Further, international environmental law now seems to focus not only on current pollution but seems to take past pollution into account in determining the extent to which polluters must "pay."

\section{Sustainable Development and Intergenerational Equity}

Like the notion of common but differentiated responsibilities, the concept of sustainable development is focused upon the interface between environmental and developmental concerns. In addition, sustainable development places the intertemporal dimensions of environmental degradation and protection, respectively, at the center of international environmental law and policy. In this regard, the concept is closely linked to the idea of intergenerational equity, ${ }^{23}$ a linkage that finds expression in the Brundtland Commission's definition of sustainable development as "development that meets the needs of the present without compromising the ability of future generations to meet their own needs." ${ }^{24}$ It is also expressed in the somewhat elliptical Principle 3 of the 1992 Rio Declaration, which states that "[t]he right to development must be fulfilled so as to equitably meet developmental and environmental needs of present and future generations." 25 The Rio Declaration was "animated" by the concept of sustainable development ${ }^{26}$ and uses the term in twelve of its twenty-seven principles. ${ }^{27}$ Yet, the precise content and contours of this basic prescription remain notoriously elusive. 
Rather than attempt to offer a definition of the concept, the declaration opted to outline various elements of sustainable development. Birnie and Boyle suggest that the declaration sets out the concept's substantive elements (such as sustainable utilization of natural resources, the integration of environment and development, a right to development, intra- and intergenerational equity, and the polluter pays principle), as well as its procedural elements (such as public participation in environmental decisionmaking and environmental impact assessment). ${ }^{28}$

In essence, then, the concept of sustainable development acknowledges the need for development but cautions that development must remain within the carrying capacity of the environment and, therefore, that environmental protection must be part of the development process. As a result, sustainable development imposes several potential limitations upon domestic development that reinforce the already noted expansion and shifts in the conceptual structure of international environmental law. Like the concept of common concern, it makes certain aspects of domestic resource management a matter of international concern. ${ }^{29}$ Further, appropriate resource use and development is not measured solely against the extent of transboundary impact but is defined according to what the environment can sustain in the longer term. Finally, in normative terms, the pragmatic intertemporal outlook of sustainable development is reinforced by the responsibilities flowing from the requirements of intergenerational equity. In short, like the concept of common but differentiated responsibilities, sustainable development is concerned with equitable balancing of contemporary environmental and developmental interests. Both concepts also have an intertemporal dimension. However, while the former concept looks, inter alia, to past activities to determine current responsibilities (and, in that sense, also aims at a form of intergenerational equity), sustainable development calls upon us to factor in future needs. 


\section{The Precautionary Principle}

The precautionary principle complements the intertemporal concepts of sustainable development and intergenerational equity. Indeed, it is difficult to see how either of the latter goals could be achieved without the approach to "scientific uncertainty" that the precautionary principle promotes. Principle 15 of the Rio Declaration posits that

[i]n order to protect the environment, the precautionary approach shall be widely applied by States according to their capabilities. Where there are threats of serious or irreversible damage, lack of full scientific certainty shall not be used as a reason for postponing cost-effective measures to prevent environmental degradation. ${ }^{31}$

Principle 15 is riddled with qualifiers and there is ongoing debate as to how great the risk of future harm and how serious the potential damage must be to trigger a precautionary obligation. Although Principle 15 of the Rio Declaration has become the most commonly cited version of the precautionary principle, some states maintain that there is no single authoritative definition and that as a result, international environmental law may promote a precautionary approach but does not contain an overarching precautionary principle. ${ }^{32}$ Be that as it may, the idea of precaution permeates the practice of states in a broad range of issue areas and at virtually all levels. It has been employed in the context of the conservation of marine resources, trade and environment matters, and an array of regional and global environmental concerns. Further, it is reflected in decisions of international tribunals and various international instruments, as well as in judicial decisions and environmental law and policy at the domestic level. ${ }^{33}$ Thus, the precautionary principle also contributes to the shifting structure of international environmental law. The principle is crucial to the implementation of the emerging intertemporal framework. It also serves to expand the reach of the transboundary paradigm expressed in Principle $21 .^{34}$ To the extent that principle 
encompasses a duty to prevent transboundary harm, ${ }^{35}$ the trigger for that duty has been a matter of debate. Following the Trail Smelter decision's requirement of "clear and convincing evidence," 36 states have maintained that preventive measures must be taken only upon proof of (pending) harm. In this context, the existence of a precautionary principle, rather than general support for a precautionary approach, could have significant implications for the rights and obligations of states.

\section{The Contributions of the Stockholm Declaration}

As I suggested earlier, the extent to which the abovementioned concepts are foreshadowed in the Stockholm Declaration is remarkable and it is worth highlighting the relevant portions of the declaration. The thrust of the concept of common concern, for example, is neatly captured in one of the "proclamations" that precede the Stockholm Declaration. It reads in part:

A growing class of environmental problems, because they are regional or global in extent or because they affect the common international realm, will require extensive cooperation among nations and action by international organizations in the common interest. ...

The ideas underlying the concept of common but differentiated responsibility, in turn, are reflected in several provisions of the Stockholm Declaration. Suffice it for present purposes to cite Principle 12, which suggests that

[r]esources should be made available to preserve and improve the environment, taking into account the circumstances and particular requirements of developing countries....

and Principle 23, which stresses the need to consider 


\section{Jutta Brunnée}

.. . the extent of the applicability of standards which are valid for the most advanced countries but which may be inappropriate and of unwarranted social cost for the developing countries. ${ }^{38}$

Although the Stockholm Declaration does not name the concept as such, it also captures various facets of the concept of sustainable development. The declaration speaks to the idea that natural resources must be used sustainably and to the need for integration of environmental protection and development. With respect to the first aspect, Principle 3 provides that "[t]he capacity of the earth to produce vital renewable resources must be maintained and, wherever practicable, restored or improved," whereas Principle 5 notes that "[t]he non-renewable resources of the earth must be employed in such a way as to guard against the danger of their future exhaustion." 39 With regard to the second aspect, Principle 13 stipulates:

In order to achieve a more rational management of resources and thus to improve the environment, States should adopt an integrated and co-ordinated approach to their development planning so as to ensure that development is compatible with the need to protect and improve the environment. ...

Principle 14 adds:

Rational planning constitutes an essential tool for reconciling any conflict between the needs of development and the need to protect and improve the environment. ${ }^{40}$

The concept of intergenerational equity also finds prominent expression in the Stockholm Declaration. According to proclamation 6, "[t]o defend and improve the human environment for present and future generations has become an imperative goal for mankind." Further, Principle 1 underlines the "solemn responsibility to protect and improve the environment for present 
and future generations," while Principle 2 stresses that "[t]he natural resources of the earth . . . must be safeguarded for the benefit of present and future generations." 41

Finally, the ideas underlying the precautionary principle are reflected in the Stockholm Declaration as well. Proclamation 6 observes in remarkably strong language that

.. . we must shape our actions throughout the world with a more prudent care for their environmental consequences. Through ignorance or indifference we can do massive and irreversible harm to the earthly environment on which our life and well-being depend.

In the same vein, Principle 6, in the context of threats posed by toxic substances and other pollutants, refers to the need to end their release in

... quantities or concentrations [that] exceed the capacity of the environment to render them harmless . . . in order to ensure that serious or irreversible damage is not inflicted upon ecosystems. ${ }^{42}$

In a number of programmatic or policy statements, then, the Stockholm Declaration captured the changing scope of the international environmental challenge and the attendant shifts in the parameters for policy responses. The declaration could not have cast these statements in legal terms at the time, but it is of note that it correctly identified the main contours of the developments in international environmental law and policy that have occurred since 1972. As I hope to have illustrated, there has been conceptual "accretion" around all of the issue markers contained in the Stockholm Declaration that I highlighted above. The legal nature and effects of this accretion remain to be explored. 


\section{The Processes of InTERnational ENVIRonMental LAW}

Up to this point, I have focused only on the shifts in the conceptual structure of international environmental law and I have left aside the thorny questions surrounding the legal status of the concepts that I canvassed. I will offer a brief survey of the state of debate on the legal status of each concept. I then want to reflect on how international environmental law operates and how its norms influence the conduct of states and shape international environmental relations. I will suggest that the legal status of structural concepts such as the ones that I discussed may not be the primary indicator of their impact.

\section{Customary Law: Five New Concepts-Thirty Years after Stockholm}

An assessment of the progress of customary law since the Stockholm Conference has the potential to be a sobering experience. In his contribution, Professor Kiss concludes that two of the Stockholm principles, Principle 1 ("right to environment") and Principle 21, have developed into customary law. Professor Kiss' conclusion with respect to Principle 21 finds confirmation, inter alia, in the International Court of Justice's (ICJ) Advisory Opinion on the Legality of the Threat or Use of Nuclear Weapons. Given the extensive reliance on the rule in Principle 21 over the last thirty years, the conclusion of the Court that it constituted a "general obligation" of states should hardly be surprising. ${ }^{43}$ What is perhaps more noteworthy is the fact that the ICJ, both in the Advisory Opinion and in the subsequent Gabcikovo-Nagymaros decision, ${ }^{44}$ did not attribute customary law status to any of the other concepts discussed in this paper, although it does allude to them. For example, in the Advisory Opinion, the Court raises the intertemporal and intergenerational dimensions of international environmental law when it notes that "the environment is not an abstraction but represents the living space, the quality of life and the very health of human beings, including generations unborn,"45 and refers to the "serious danger to future generations" posed by 
nuclear weapons. ${ }^{46}$ In Gabcikovo, the ICJ provides the most oblique of references to the erga omnes quality of international environmental law when it prefaces a reference to its Advisory Opinion statement on the general obligation regarding transboundary harm by stressing "the significance it attaches to respect for the environment, not only for States but also for the whole of mankind. ${ }^{47}$ Also in Gabcikovo, the Court gives a nod to the idea of precaution but does not endorse the precautionary principle when it declares itself to be "mindful that, in the field of environmental protection, vigilance and prevention are required on account of the often irreversible character of damage to the environment and of the limitations inherent in the very mechanism of reparation of this type of damage. ${ }^{48}$ Finally, with respect to sustainable development and the evolution of international environmental law in general, the ICJ notes that

. . . new norms and standards have been developed, set forth in a great number of instruments during the last two decades. Such new norms have to be taken into consideration, and such new standards given proper weight, not only when States contemplate new activities but also when continuing with activities begun in the past. This need to reconcile economic development with the protection of the environment is aptly expressed in the concept of sustainable development. ${ }^{49}$

Thus, some thirty years after Stockholm, the ICJ found itself in a position to confirm the customary nature of Principle 21 and to acknowledge the emergence of "new norms," but not to identify any of the principles discussed in this paper as customary law. As disappointing as this state of affairs may seem at first glance, the ICJ is hardly to blame. Measured against the prevailing criteria for the existence of customary law, ${ }^{50}$ it is, indeed, impossible or at least difficult to conclude that the five concepts highlighted here are customary law. 


\section{Jutta Brunnée}

With respect to the concept of common concern, a first difficulty rests in the fact that its normative content is hard to pinpoint. As discussed, the concept is in the first instance a participation rule, giving states standing regarding the concern, perhaps even requiring their cooperation. In the second instance, the concept has the potential to limit states' rights to use their resources beyond the constraints imposed by Principle 21 if that use creates or aggravates a common concern. Important legal implications of the common concern concept might thus flow from the identification of cases-the common concerns-in which rights and obligations exist erga omnes. ${ }^{51}$ In this respect, the concept of common concern could connect international environmental law to the law of state responsibility, and the possibility of invocation of responsibility for breaches of obligations owed to a group of states, or to the international community as a whole. ${ }^{52}$ However, while it may be possible to posit potential legal consequences of the existence of a common concern, it remains unclear according to precisely what criteria such concerns are to be identified. ${ }^{53}$

The inquiry into the legal status of the concept of common but differentiated leads to similarly inconclusive results. As noted earlier, it is possible to identify a number of practical manifestations of the concept and to extrapolate its potential legal implications from these. Overall, the concept is less a rule of conduct than a principle that affects the structuring or consequences of other obligations, notably in the treaty context. ${ }^{54}$ Although the concept is widely employed, it is not clear that it has acquired customary law status. ${ }^{55}$ Indeed, recently, some states have shown reluctance to include the principle as such in environmental agreements. It has been argued, for example, that the principle is "not necessary" because its goals can be achieved simply through appropriate structuring of an agreement, and "not helpful" because its meaning and legal implications are unclear. ${ }^{56}$ Of course, this effort to resist the principle may be a rear-guard action that actually suggests less the principle's weakness than its potential strength. After all, the principle may point to developed country 
obligations to assume the main burdens of global environmental protection.

The perhaps most lively debate has taken place with respect to the legal status of the concept of sustainable development. Assessments range from the conclusion that the concept is not even normative in nature, ${ }^{57}$ to the view that it is an umbrella concept that is fleshed out by other principles, ${ }^{58}$ all the way to the assertion that it is a normative concept with erga omnes implications and part of "modern international law." "T9 The perhaps most nuanced examination of the legal impact of sustainable development was recently offered by Vaughn Lowe. He suggested that the concept has normative force as an element of legal reasoning. He aptly described sustainable development as

. . . a legal concept exercising a kind of interstitial normativity, pushing and pulling the boundaries of true primary norms when they threaten to overlap or conflict with each other. ${ }^{60}$

Although the concept of intergenerational equity is more explicitly normative in outlook, its legal status is also unclear at this stage. It has been argued that the obligation of one generation to pass on to the next generation the natural and cultural resources of the earth in no worse conditions than they were received requires the "conservation of options," "the conservation of quality," and the "conservation of access." 61 However, it is not clear that the concept has evolved in a manner that spells out these requirements. As suggested earlier, while the concept finds expression in most contemporary international environmental instruments, it appears to have become melded into the concept of sustainable development. In terms of state practice and opinio juris, the distinctive legal content of intergenerational equity may, therefore, have become obscured rather than clarified. ${ }^{62}$

Finally, although the precautionary principle may be the most likely candidate for customary law status, doubts linger in this case as well. To be sure, an increasing number of observers conclude 
that the principle is binding custom, ${ }^{63}$ including a recent and very carefully executed study of international practice and academic literature. ${ }^{64}$ Yet, there are also skeptical voices and, ${ }^{65}$ as previously mentioned, a number of states continue to assert that there exists no legally binding precautionary principle. Rather, they argue, international environmental law merely reflects various manifestations of a precautionary approach. I will not enter into the fray of this debate, except to say that, given the manifest impact of the precautionary principle, the debate has assumed a slightly surreal flavor. ${ }^{66}$ Indeed, the story of the precautionary principle is one illustration of the argument that I now wish to develop: that the influence of the principles that I have discussed may not, in fact, depend on whether or not they are formally legally binding.

\section{Beyond Custom}

So far, this paper may appear to suffer from a disjuncture. Having spent considerable time on outlining elements of the new structure of international environmental law, I proceeded to conclude that none of the structural concepts I discussed have clearly established themselves as customary law-with the possible exception of the precautionary principle. One might ask whether the structural shifts I have sketched, then, are more apparent than real. If there has been little change in the rules of customary international environmental law, can its structure really have shifted? While we may have understood-and have understood since the Stockholm Conference-that certain issues required our attention and efforts, have we developed international environmental law so as to enable it to meet the attendant challenges, to remain relevant?

If we were to make formal bindingness the measure of legal success, we would have to answer these questions largely in the negative. Indeed, some have mourned the end of a "golden era of international law,"67 and international environmental law's "regression” to growing reliance on 
. . . supposedly agreed-upon "rules" of so-called soft law, which are so deprived of any mandatory or imperative language and of any reciprocal rights and obligations that they could hardly be recognized as rules of international law at all. ${ }^{68}$

In my view, this type of assessment does not do justice to the diverse processes through which international environmental law actually operates. And to the extent that there has been a shift away from formally binding processes and outcomes, this shift may, in fact, not weaken but expand international environmental law's ability to influence. To be sure, I do not mean to deny that formally binding rules may be important in certain contexts or that enforceability may have potential benefits in certain settings. My point is, rather, that international environmental norms are rarely used in a litigation or enforcement-oriented context. In light of this fact, Daniel Bodansky, in an essay entitled "Customary (and not so Customary) International Environmental Law," questioned the preoccupation with whether particular rules are legally binding or not. ${ }^{69}$ Whatever one's views in this regard, for the most part international environmental law actually influences through horizontal rather than hierarchical processes. It can exert "compliance pull" and influence states in the absence of enforcement mechanisms, notably where norms are seen as legitimate. ${ }^{70}$ Or it shapes international discourse, such as negotiation or diplomacy, helping to justify positions and to persuade other actors. ${ }^{71}$ In my view, international environmental law furnishes an array of examples that suggest that its ability to operate in this fashion does not necessarily depend on its formal bindingness. $^{72}$

In the treaty context, we have witnessed how broad frameworks serve to shape the context within which detailed rules are generated and interpreted. ${ }^{73}$ Indeed, the adoption of a multilateral environmental agreement typically is not the endpoint of the international legal process but the beginning. What is more, many of the rules, principles, and guidelines generated within 
multilateral environmental agreements are adopted through decisions of Conferences of the Parties or similar bodies and are thus not formally binding. Yet, the relevant standards appear to be treated as a sort of quasi-law, and it is not clear that they are any less influential than "hard" law would be. ${ }^{74}$

In the context of the principles of international environmental law, there is ample evidence of their ability to exert influence even while their legal status remains contested. The precautionary principle may serve as an example. At the international level, the principle (or approach) has found expression in an array of environmental agreements, as well as in trade agreements. ${ }^{75}$ As a result, the principle has come to influence the evolution, interpretation, and implementation of these agreements. ${ }^{76}$ The concept of precaution has also been taken into consideration in international dispute settlement processes. ${ }^{77}$ The principle's impact at the domestic level is perhaps best illustrated through the practice of one of the states that continues to deny its customary law status-Canada. ${ }^{78}$ Notwithstanding this official position, the precautionary principle is shaping Canadian law and policy in decisive ways. For example, the preamble to the Canadian Environmental Protection Act expresses a commitment to "implementing the precautionary principle" (emphasis added) and makes reference to Canada's international obligations. ${ }^{79}$ Similarly, the Supreme Court of Canada invoked the precautionary principle in the context of a decision regarding the jurisdiction of a municipality to regulate lawn chemicals. Relying on various scholarly authors, the Court noted that there might be "currently sufficient state practice to allow a good argument that the precautionary principle is a principle of customary international law." 80 The Court also confirmed that, in any case, the values reflected in international law "inform the contextual approach to statutory interpretation and judicial review."81 Finally, at the level of government policy, suffice it to point to a recent discussion paper. While the paper reaffirms Canada's position on the legal status of the precautionary principle, ${ }^{82}$ it notes that Canada supports the statement in Principle 15 of the Rio Declaration. ${ }^{83}$ The very purpose of the paper is to outline guiding principles to 
The Stockholm Declaration and the Structure and Processes of International Environmental Law

"support consistent, credible and predictable policy and regulatory decision-making when applying the precautionary approach/ principle."84

The precautionary principle, due to its applicability to all levels of decision-making and planning, has shown itself capable of exerting influence both nationally and internationally. Other principles, like common concern or common but differentiated responsibilities, are by definition focused on international relations. These differences notwithstanding, my sense is that it would be possible to illustrate concretely how all of the principles that I have identified in this paper have reshaped the structure of international environmental law in the manner I suggested earlier, and do influence the conduct of states. Through diverse processes, they shape approaches to international treaty-making, guide and constrain legal arguments, and influence judicial decision-making. In all of these respects, their precise legal status appears to be of secondary importance. Whether they are formally binding or not, it seems unlikely that arguments or decisions in blatant disregard of any of the five principles would be persuasive and could be sustained in the long run.

\section{CONCLUSION}

The Stockholm Declaration did mark an important moment in the evolution of international environmental law. In my view, its significance should not be measured against the degree to which its principles have, or have not, become binding as customary international law. Rather, the declaration should be appreciated as the beginning of a normative process. Of necessity, such a process begins with the identification of issues of common concern. The perhaps most significant contribution of the Stockholm Declaration, then, was that it looked beyond the transboundary concerns of the day and highlighted the global nature of environmental degradation and, most importantly, the unavoidable interface between environment and development issues. In so doing, the declaration also provided a reference point, a marker of 


\section{Jutta Brunnée}

the issues that the structure of international environmental law was not equipped to address. Thirty years after the Stockholm Declaration, we may not have formally binding rules to fill all of the gaps identified at Stockholm. But we can say that shared normative understandings have begun to emerge that have had a significant impact on both the structure and processes of international environmental law. ${ }^{85}$ 


\section{Notes}

${ }^{1}$ Reprinted in 11 I.L.M. 1416 (1972).

${ }^{2}$ See, e.g., T. E. J. Campbell, The Political Meaning of Stockholm: Third World Participation in the Environment Conference Process, 3 STAN. J. InT’L STUD. 138 (1973); N.J. Faramelli, Toying with the Environment and the Poor: A Report on the Stockholm Environmental Conferences, 2 ENVT'L. AfFAIRS 469 (1972); D. A. Kay \& E. B. Skolnikoff, International Institutions and the Environmental Crisis: A Look Ahead, 26 INT'L ORG. 469 (1972); The Editors, The Stockholm Conference: A Synopsis and Analysis, 8 STAN. J. INT’L STUD. 31 (1973).

${ }^{3}$ Textbooks tend to describe the history of international environmental law as unfolding in various phases (usually divided into "pre-Stockholm," "Stockholm to Rio," and "Rio to present"), with the Stockholm Conference marking the emergence of modern international environmental law. See, e.g., U. BEYERLIN, UMWELTVÖLKERRECHT, Part 1 (2000); D. HunTER, et al., InTERNATIONAL Environmental LaW AND Policy, Ch. 6 (1998); P. SANDS, Principles of INTERNATIONAL ENVIRONMENTAL LAW: FRAMEWORKS, STANDARDS AND IMPLEMENTATION, Ch. 2 (1995) (suggesting four distinct phases).

${ }^{4}$ See, e.g., D. Wirth, The Rio Declaration on Environment and Development: Two Steps Forward and One Back, or Vice Versa? 29 GeORGIA L. REV. 599 (1995), at 604 (note 18); T. BRENTON, ThE GREENING OF MACHIAVELLI: ThE EVOLUTION OF INTERNATIONAL ENVIRONMENTAL POLITICS, at 39 (1994).

${ }^{5}$ For detailed discussions of the South-North dynamics surrounding the Stockholm Conference, see K. Mickelson, South, North, International Environmental Law, and International Environmental Lawyers, 11 Үвоок InT'L ENV. L. 52 (2000); R. K. L. Panjabi, From Stockholm to Rio: A Comparison of the Declaratory Principles of International Environmental Law, 21 DenVER J. INT’L ENV. L. \& POL. 215, 236-245 (1993).

${ }^{6}$ See Mickelson, ibid. (arguing, however, that international environmental law still has not truly integrated environmental and developmental issues).

7 This discussion will not focus on principles pertaining to human rights to environment or to citizen participation. These issues are addressed in the contribution by Alexandre Kiss.

${ }^{8}$ For a detailed discussion of the conceptual origins and evolution of international environmental law, see J. Brunnée, Toward Effective International Environmental Law-Trends and Developments, in S. A. Kennett, ed. LAW AND PRocess in ENVIRONMENTAL MANAGEMENT, 217 (1993).

${ }^{9}$ Principle 21 has since been captured in a variety of other instruments, including in the Rio Declaration on Environment and Development; reprinted in 31 I.L.M. 876 (1992). For the purposes of this paper, "Principle 21" will be used as shorthand for the rule that states have the sovereign right to exploit their 
resources, and the responsibility to ensure that activities within their jurisdiction do not cause significant transboundary harm.

${ }^{10}$ For a discussion of this issue in the context of the International Law Commission's efforts to complete the Articles on State Responsibility, see J. Crawford et al., The ILC's Articles on Responsibility of States for Internationally Wrongful Acts: Completion of the Second Reading, 12 EUR. J. INT'L L. 963, at 975-976 (2001).

${ }^{11}$ For a detailed discussion of the concept of common concern, see P. BIRNIE \& A. E. BOYLE, INTERNATIONAL LAW AND THE ENVIRONMENT, 2nd ed., at 97-100 (2002); see also J. Brunnée, A Conceptual Framework for an International Forests Convention: Customary Law and Emerging Principles, in Canadian Council on International Law, ed., GLOBAL FORESTS AND INTERNATIONAL ENVIRONMENTAL LAW, 41, at 55-62 (1996).

${ }^{12}$ United Nations Framework Convention on Climate Change, preamble, reprinted in 31 ILM 849 (1992) [hereinafter UNFCCC].

${ }^{13}$ Convention on Biological Diversity, preamble, reprinted in 31 ILM 822 (1992).

${ }^{14}$ Rio Declaration, supra note 9.

${ }^{15}$ See UNFCCC, supra note 12, sixth preambular recital.

${ }^{16}$ See id., and Articles 3.1, 4.1.

${ }_{17}$ Montreal Protocol on Substances that Deplete the Ozone Layer, 26 I.L.M. 1550 (1987); as adjusted and amended June 29, 1990, 30 I.L.M. 539 (1990); further adjusted and amended November 25, 1992, 32 I.L.M. 875 (1992); further adjusted and amended September 17, 1997; further adjusted December 3, 1999; consolidated text available at <http://www.unep.org/ozone/montreal.shtml> (visited May 13, 2002).

${ }^{18}$ Supra note 13.

${ }^{19}$ For a detailed discussion, see BIRNIE \& BOYLE, supra note 11, at 100-104.

${ }^{20}$ See, e.g., Article 5 of the Montreal Protocol, supra note 17, which provides different baseline years and different timelines for developing country commitments. See also Article 4.2 of the UNFCCC, supra note 12, which envisages emission limitation commitments only for developed countries and countries with economies in transition.

${ }^{21}$ See, e.g., Article 10 of the Montreal Protocol, supra note 17, which establishes a financial mechanism for the purposes of financial and technical assistance to developing countries to enable their compliance with protocol commitments.

${ }^{22}$ See, e.g., Article 5.5 of the Montreal Protocol, supra note 17, which provides that the implementation by developing country parties of their commitments "will depend upon the effective implementation of" financial cooperation and technology transfer. Similarly, Article 7 of the UNFCCC, supra note 12, stipulates that the "extent to which developing country Parties will effectively implement their commitments . . . will depend upon the effective 
implementation by developed country Parties of their commitments . . . related to financial resources and transfer of technology.”

23 See Edith Brown Weiss, The Emerging Structure of International Environmental Law, in N. J. Vig \& R. S. Axelrod, eds., THE GLOBAL ENVIRONMENT: INSTITUTIONS, LAW AND POLICY, 98, at 106-107 (1999).

${ }^{24}$ World Commission on Environment and Development, OuR COMMON FUTURE, at 43 (1987).

${ }^{25}$ Rio Declaration, supra note 9. On the provision's wording, see Wirth, supra note 4 , at 627-628.

${ }^{26}$ Wirth, supra note 4 , at 625 .

${ }^{27}$ Rio Declaration, supra note 9, Principles 1, 4, 5-9, 12, 20-22, 24, and 27.

${ }^{28}$ See BIRNIE \& BOYLE, supra note 11, at 86-95.

${ }^{29} \mathrm{Id}$., at 85 .

${ }^{30}$ For further discussion of the concept of sustainable development and its linkages to the notions of intergenerational equity and common but differentiated responsibilities, see Brunnée, supra note 11, at 62-69.

${ }^{31}$ Rio Declaration, supra note 9.

32 See, e.g., Government of Canada, A Canadian Perspective on the Precautionary Approach/Principle-Proposed Guidelines (September 2001), at 5; available at <http://www.dfait-maeci.gc.ca/tna-nac/prec-booklet-e.pdf > ("Rules of customary international law are developed by the common consent of States. Due to an absence of clear evidence of uniform State practice and opinio juris, Canada does not yet consider the precautionary principle to be a rule of customary international law").

${ }^{33}$ See, generally, BIRNIE \& BOYLE, supra note 11 , at 115-121.

${ }^{34}$ For further discussion, see Brunnée, supra note 11, at 71-74.

${ }^{35}$ See Corfu Channel Case (United Kingdom v. Albania), [1949] I.C.J. Rep. 4.

${ }^{36}$ Trail Smelter Case (United States v. Canada), (1941) 3 R.I.A.A. 1905.

${ }^{37}$ Stockholm Declaration, supra note 1, proclamation 7.

${ }^{38} \mathrm{Id}$. See also proclamation 4 (noting that "in the developing countries most of the environmental problems are caused by under-development”); Principle 9 (referring to the need for "the transfer of substantial quantities of financial and technological assistance"); and Principle 11 (calling for appropriate steps "with a view to reaching agreement on meeting the possible national and international economic consequences resulting from the application of environmental measures" in developing countries).

${ }^{39}$ Stockholm Declaration, supra note 1.

${ }^{40} \mathrm{Id}$.

${ }^{41} \mathrm{Id}$.

${ }^{42} I d$. 
${ }^{43}$ ICJ, Advisory Opinion on the Legality of the Threat or Use of Nuclear Weapons, reprinted in 35 I.L.M. 809 (1996), at para. 29 [hereinafter Advisory Opinion].

${ }^{44}$ ICJ, Case Concerning the Gabcikovo-Nagymaros Project, reprinted in 37 I.L.M. 162 (1998) [hereinafter Gabcikovo].

${ }^{45}$ Advisory Opinion, supra note 43.

${ }^{46} I d$., at para. 35.

${ }^{47}$ Gabcikovo, supra note 44, at para. 53.

${ }^{48} I d$., at para. 140.

${ }^{49} \mathrm{Id}$.

50 For a recent discussion, see A. E. Roberts, Traditional and Modern Approaches to Customary International Law: A Reconciliation, 95 AM. J. INT’L L. 757 (2001).

${ }^{51}$ See also BIRNIE \& BoYLE, supra note 11, at 98-100.

${ }^{52}$ See International Law Commission, State responsibility-Titles and texts of the draft articles on Responsibility of States for internationally wrongful acts adopted by the Drafting Committee on second reading, U.N. Doc. A/CN.4/L.602 and Corr.1 and L.602/Rev.1, 26 July 2001, Article 48. Available at <http://www.un.org/law/ilc/sessions/53/53docs.htm> (visited April 14, 2002). And J. Peel, New State Responsibility Rules and Compliance with Multilateral Environmental Obligations: Some Case Studies of How the New Rules Might Apply in the International Environmental Context, 10 REV. EuR. CoM. \& INT'L ENVT'L. L. 82 (2001).

${ }^{53}$ It has been suggested that the concept of common concern has no "normative effect” whatsoever. See BEYERLIN, supra note 3, at 60.

${ }^{54}$ See, generally, D. French, Developing States and International Environmental Law: The Importance of Differentiated Obligations, 49 INT'L \& COMP. L. Q. 35 (2000).

${ }^{55}$ Although some suggest that it is well on the way to becoming customary law. See BEYERLin, supra, note 3, at 60.

${ }^{56}$ Remarks of Susan Biniaz, Assistant Legal Adviser, U.S. Department of State, $96^{\text {th }}$ Annual Meeting of the American Society of International Law, Washington, D.C., March 16, 2002 (notes on file with author).

${ }^{57}$ BEYERLIN, supra note 3, at 59.

${ }^{58}$ SANDS, supra note 3, at 198-208. See also Commission for Sustainable Development, Report of the Expert Group Meeting on Identification of Principles of International Law for Sustainable Development, U.N. Doc. E/CN.17/1996/17/Add.1 (1 March 1996).

${ }_{59}$ Gabcikovo, supra note 44, at 213, 217 (Separate Opinion of Vice-President Weeramantry).

${ }^{60}$ V. Lowe, Sustainable Development and Unsustainable Arguments, in A. Boyle \& D. Freestone, eds., InTERNATIONAL LAW AND Sustainable 
Development: Past Achievements And Future Challenges, 19, at 31 (1999).

${ }^{61}$ E. BRown Weiss, In FAIRNESS to FutURe GENERATIONS: INTERNATIONAL LAW, COMMON PATRIMONY AND INTERGENERATIONAL EQUITY, at 37-45 (1989).

${ }^{62}$ For skeptical assessments, see BIRNIE \& BoYLE, supra note 11 , at 90-91; BEYERLIN, supra note 3, at 60 .

${ }^{63}$ See, e.g., J. Cameron, The Precautionary Principle in International Law, in T. O'Riordan, et al., eds., REINTERPRETING THE PRECAUTIONARY PRINCIPLE, 113 (2001).

64 A. Troumborst, Evolution and Status of the Precautionary PRINCIPLE IN INTERNATIONAL LAW, at 284 (2002).

${ }^{65}$ See, e.g., C. D. Stone, Is There a Precautionary Principle? 31 EnVT’L. L. REP. 10790 (2001).

${ }^{66}$ See also, D. Freestone, Caution or Precaution: "A Rose By Any Other Name . ..”? 10 YBoOK INT’L ENV. L. 25, at 26 (1999) (noting that the debates about the legal status of the precautionary principle "have a distinctly 1990s feel about them"); and BIRNIE \& BOYLE, supra note 11, at 120 (concluding that "the propositions that it is, or that it is not, customary international law are too simplistic").

${ }^{67}$ A. Székely, Compliance with Regulatory Treaties: The Empirical Evidence. A Commentary on the Softening of International Environmental Law, in American Society of International Law, Proceedings of THE $91^{\text {sT }}$ ANNUAL MEeting: IMPLEMENTATION, COMPLIANCE AND EFFECTIVENESS, 234, at 236 (1997).

${ }^{68} I d$., at 235.

69 D. Bodansky, Customary (and not so Customary) International Environmental Law, 3 INDIANA J. GLOBAL LEG. STUD. 105 (1995).

${ }^{70}$ See T. M. Franck, Legitimacy in the International System, 82 AM. J. INT’L L. 705 (1988).

71 See J. Brunnée \& S. J. Toope, International Law and Constructivism: Elements of an Interactional Theory of International Law, 39 CoL. J. TRANSNAT'L. L. 19, at 64-74 (2000).

${ }^{72}$ I will sidestep the more complex question of whether binding legal status gives norms a distinctive ability to influence states.

${ }_{73}^{73}$ For an overview, see BIRNIE \& BOYLE, supra note 11, at 209-215.

${ }^{74}$ See J. Brunnée, COPing with Consent: Lawmaking under Multilateral Environmental Agreements, 15 LEIDEN J. INT'L L. 1 (2002).

${ }^{75}$ See BIRNIE \& BOYLE, supra note 11, at 115-121.

${ }^{76}$ See, generally, A. E. Boyle, Some Reflections on the Relationship of Treaties and Soft Law, 48 INT'L \& COMP. L. Q. 901 (1999).

${ }^{77}$ See WTO Appellate Body, Measures Concerning Meat and Meat Products, WTO Doc. WT/DS26/AB/R (16 January 1998); Southern Bluefin Tuna Cases (Provisional Measures), (1999) ITLOS Nos. 3 \& 4. 
${ }^{78}$ Government of Canada, supra note 32.

${ }^{79}$ Canadian Environmental Protection Act, S.C. 1999, c.33.

${ }^{80} 114957$ Canada Ltée (Spraytech, Société d'arrosage) v. Hudson (Town), [2001] S.C.C. 40, at para. 32.

${ }^{81}$ Id., at para. 30. See also Baker v. Canada (Minister of Citizenship and Immigration), [1999] 2 S.C.R. 817.

${ }^{82}$ See Government of Canada, supra note 32.

${ }^{83} I d$., at 1.

${ }^{84} I d$., Foreword.

${ }^{85}$ See also L. B. Sohn, The Stockholm Declaration on the Human Environment, 14 HARVARD J. INT'L L. 413, at 513-515 (1973) (predicting that the declaration, its non-binding and policy-oriented character notwithstanding, would have this type of impact). 
